\title{
The Effect of Work Stress, Work Environment, and Occupational Health and Safety on Employee Productivity
}

\author{
Devina Pramestuti ${ }^{1}$, Didin Hikmah Perkasa ${ }^{2}$ \\ \{devina.pramestuti@undira.ac.id ${ }^{1}$, didin.hikmah.perkasa@undira.ac.id ${ }^{2}$ \}
}

Universitas Dian Nusantara, Jakarta, Indonesia ${ }^{1}$, Universitas Dian Nusantara, Jakarta, Indonesia ${ }^{2}$

\begin{abstract}
The main objective of this research is to measure the Work Productivity of PT Indotama. Using a quantitative descriptive approach. The data in the study were obtained from 62 respondents who were employees of PT Indotama. Data analysis in this study is used an alternative method of structural equation modeling (SEM), namely partial least square (PLS). The first stage in this study was to test the validity of the questions for each variable along with its reliability. The second stage examines the factors that affect work productivity. The results of this study that the variable works stress and occupational safety and health has posited and significant effect on work productivity, for work environment variable does not affect on work productivity of PT Indotama.
\end{abstract}

Keywords: Work Stress, Work Environment, Occupational Health and Safety, Work Productivity

\section{Introduction}

In this era, one of factors that determine the success of a company is in the employees (human resources). Human resources are one of the determinants of a company's success because the role of human resources as a valuable asset is to plan, implement, and control various company operational activities. The success or failure of a company in maintaining the company's existence starts from the company's efforts to manage human resources, therefore the company must pay attention to what is needed by an employee to be able to work optimally and productively.

According to (1) work productivity is defined as a measure that shows the consideration between the input and output issued by the company and the role of labor that is owned by the time unit. Every organization, whether in the form of a company or another, will strive so that employees involved in organizational activities can provide achievements in the form of high work productivity to realize the goals that have been set, one of which is so that work productivity can be achieved, the leadership in the company must pay attention to a good work environment so that employees can produce high productivity so that employees do not experience work stress in their work environment, besides that employees must also pay attention to occupational health safety that has been implemented within the company.

The factors that influence productivity are work stress, work environment, and occupational health insurance, which are management actions to encourage employees to meet the demands of various provisions on work efficiency and work effectiveness. It can be said that the work stress of employees has an effect on work productivity so that the assessment of work productivity is seen in the form of production output produced. 
Phenomenon in this study is the failure to achieve overall work productivity due to various problems, especially internal ones, including excessive workload resulting in work stress, lack of rest time and in completing tasks, the time provided is only minimal and has to do overtime work, lack of support facilities. in completing tasks, unclear job descriptions and other tasks that are not his responsibility become a separate burden, as well as a work environment that makes him feel bored in doing work. Some of these things trigger work stress on employees and lead to inadequate production.

According to (2), it is common that Human Resources are the greatest asset for an organization. One way that companies can do to increase work productivity is by paying attention to employee work stress. Employee stress needs to be resolved as early as possible by a leader, so that things that are detrimental to the company can be overcome. People who experience work stress become nervous and experience chronic anxiety. They often become grumpy, aggressive, and not relaxed or notice uncooperative attitudes.

In the long term, employees who cannot withstand work stress are no longer able to work in the company. [3] define job stress as an adjustment response, mediated by individual differences or psychological processes, as a result of each circular action, situation or events that impose excessive psychological and physical demands on a person.

A good work environment condition is appropriate if humans can carry out activities in an optimal, healthy, safe and comfortable manner. The consequences of the work environment can be seen in the long term. According to [1], the work environment is a very important component in employees carrying out work activities. By paying attention to a good work environment or creating working conditions that are able to provide motivation to work, it will have an influence on employee enthusiasm or morale.

The unfavorable work environment can be seen from the heavy workload of employees so that they do not finish their work according to the set time, so that a lot of work piles up and does not reach the target expected by the company resulting in employees experiencing frustration with the work that must be done. Supervision by the leadership of employees that is not yet optimal has resulted in an inadequate work environment so that the improvement of the work environment is not in accordance with the needs and desires of employees.

Occupational health and safety (K3) in companies in Indonesia is sometimes still being neglected. Occupational health and safety (K3) is one of the human rights and an effort to improve the quality of work of employees in the company itself. According to [4] occupational health and safety (K3) is a protection effort aimed at making workers and other people in the workplace or always in a safe and healthy condition so that every source of production can be used safely and efficiently.

the growing needs of production, industrial development is required to follow and independently lead to the era of Industrialization. The process of advanced industrialization is marked by, among others, electrification and modernization mechanisms in nature, in such a situation, the use of modern installation machines and tools and hazardous materials is increasing, besides facilitating the production process it can also increase the number and sources of danger in the workplace. In other cases there will also be a dangerous work environment and an increase in the work intensity of the workforce's operational.

Companies need to implement $\mathrm{K} 3$ programs which are expected to reduce the rate of occupational accidents and occupational diseases, which in turn will improve company performance and employee work productivity. Employees are encouraged to realize the importance of the implementation of occupational health and safety for employees and companies, so that the implementation of occupational health and safety (K3) is very necessary and very important, because it helps to realize good work productivity. 
Based on the results of interviews with the head of the production department, the phenomenon that occurs in the production section regarding occupational health safety (K3) is that it does not reach an accident that is too severe (death) but only minor accidents such as electrocution, being pinched, falling and hands scratched by acrylic material.

Based on the description above, the formulation of the problem in this tudy:

1) Does job stress have a significant effect on work productivity of employees at PT. Main Indomika?

2) Does the work environment have a significant effect on work productivity of employees at PT. Main Indomika?

3) Does occupational health and safety have a significant effect on work productivity of employees at PT. Main Indomika?

The objectives of the research are:

1) To determine the effect of work stress on employee productivity at PT. Main Indomika

2) To determine the effect of work environment on employee productivity at PT. Main Indomika

3) To determine the effect of occupational health and safety (K3) on employee work productivity at PT. Main Indomika

\section{Literature Review}

\subsection{Stres Work}

According to (4) In the long term, employees who cannot withstand work stress are no longer able to work in the company. At an increasingly severe stage, stress can make employees become sick or even resign.

According to [3], defining work stress is an adjustment response, mediated by individual differences or psychological processes, as a result of any circular actions, situations or events that determine excessive psychological and physical demands on a person. According to [5], job stress is an unexpected reaction as a result of the high demands of the company environment on someone.

Indicators of work stress according to research by [6], namely:

1. Working conditions, including: (a) Overwork quantitatively; (b) Overwork qualitatively; (c) Work Schedule

2. Stres Because of the Role: Role ambiguity

3. Interpersonal Factors: (a) Lack of work performance and social support systems; (b) Lack of management attention to employees

4. Development Career: (a) The promotion to a lower position than his ability; (b) The promotion to a higher position than his ability; (c) The security of his job

5. Structure Organization: (a) Rigid and hostile structure; (b) Supervision and unbalanced training; (c) Not being involved in making decisions

\subsection{Work environment}

The work environment in a company is very important for management to be focused on. Even though the work environment does not carry out the production process of a company, the work environment has a direct influence on employees. Work environment is an atmosphere in which employees work and carry out activities every day.

According to [7] states that the work environment is the tool and materials faced, the surrounding environment where a person works, his work methods, and work arrangements both as an individual and as a group. According to [1], the work environment is a very important 
component in employees carrying out work activities. By paying attention to a good work environment or creating working conditions that are able to provide motivation to work, it will have an influence on employee enthusiasm or morale.

Dimensions and Indicators of Work Environment. According to [7] in general the dimensions and indicators of the work environment consist of a physical work environment and a physical work environment.

\section{a. Physical Environment}

Factor is the environment around the workers themselves. Conditions in the work environment can affect employee work productivity which includes:

1. Workspace Plan. Including the suitability of the arrangement and layout of work equipment, this has a major effect on the comfort and work skills of employees.

2. Job Design. Covering work equipment and work procedures or work methods, work equipment that is not suitable for their work will affect the health of employees' work.

3. Working Environment Conditions. Lighting and noise are closely related to the comfort of workers at work. Air circulation, room temperature, and appropriate lighting greatly affect a person's condition in carrying out his duties.

4. Visual Privacy and Acoustical Privacy Levels. A certain level of work requires a workplace that can provide privacy for its employees. What is meant by privacy here is "privacy" regarding matters relating to himself and his group. While acoustical privacy relates to hearing.

b. Psychic Environment office

Psychic environment is things that are related to social and organizational relationships.

Psychological conditions that affect employee job satisfaction are:

1. Excessive work. Excessive work with limited or urgent time in completing a job will cause stress and tension on employees, so that the results obtained are not optimal.

2. Poor System supervision. Poor and inefficient supervisory systems can lead to other dissatisfaction, such as instability in the political atmosphere and a lack of feedback on work performance.

3. Frustration. Frustration can have an impact on the hindrance of achieving goals, for example company expectations are not in line with employee expectations, if this continues it will cause frustration for employees.

4. Changes in all forms. Changes that occur in work will affect the way people work, for example changes in the work environment such as changes in types of work, changes in organizations and changes in company leaders.

5. Dispute between individuals and groups. This happens when both parties have the same goals and compete to achieve these goals. These disputes can have a negative impact, namely the occurrence of disputes in communication, lack of cohesiveness and cooperation. While the positive impact is the existence of positive efforts to resolve disputes in the workplace, including: competition, status problems and differences between individuals.

\subsection{Occupational Health and Safety (K3)}

According to Meggisinson in [8], the term safety includes both the terms safety risk and health risk. In the field of employment, the two terms are distinguished. Work safety indicates conditions that are safe or safe from suffering, damage or loss in the workplace. Safety risks are aspects of the work environment that can cause fire, fear of electricity, cuts, bruises, irritability, fractures, loss of organs, vision and hearing. These are often associated with company equipment or the physical environment and include work tasks that require maintenance and training. 
Meanwhile, occupational health indicates a condition that is free from physical, mental, emotional or pain disorders caused by the work environment.

According to Ardana [4], occupational safety and health (K3) is a protection effort aimed at ensuring that workers and other people are in the workplace or are always in a safe and healthy condition so that every source of production can be used safely and efficiently.

Occupational health and safety variables are measured using four dimensions, namely:

1. Use of work equipment.

2. Air setting.

3. Physical condition of employees.

4. Lighting settings.

Dimensions and Indicators of Occupational Health and Safety (K3). According to Handoko

[9] states that the increasingly important areas of personnel management are:

1. Pemaintain the safety and health of employees. (a) Pay attention to safer and healthier working conditions. (b) Provide work protection. (c)Provide proper equipment.

2. Organizational responsibility for employee safety and health. (a)Requires the handling of a specialist. (b) Under the supervision. (c) Provide insurance to employees.

3. Creating a healthy work environment. (a) Pay attention to machine conditions that are unsafe or unhealthy. (b) Pay attention to humidity and air temperature settings. (c) Pay attention to cleanliness of the environment.

4. Employee safety and health programs. (a)Perform proper maintenance of factory facilities. (b) Use manuals and safety tools. (c) Educate employees about safety.

\subsection{Employee Work Productivity}

According to [9], productivity is generally defined as the relationship between output (goods or services) and input (labor, materials and money). Productivity is a measure of productive efficiency, comparison between output and input. Input is often limited by labor, while output is measured in physical terms, form, and value.

According to [10], productivity is the comparison of a certain number of outputs with a certain number of inputs for a certain period of time.

Work productivity is defined as a measure that shows the consideration between the input and output issued by the company and the role of labor that is owned by the time unit [1] .

Dimensions and Indicators Employee Productivity. Productivity is things that are very important for employees in the company. With work productivity it is expected that work will be carried out efficiently and effectively, to measure work productivity, an indicator is needed according to [9], which are as follows:

1. Ability. (a) The skills that a person or employee possesses. (b) Professionalism in working in an organization or company.

2. Upcgrade the results achieved. Take advantage of the productivity that has been achieved

3. Spirit of work. (a) Applied work ethic in increasing yield. (b) Results achieved by employees that have been determined by the organization or company

4. Self-development. (a) Seeing challenges to encourage yourself. (b) Expectations to be faced

5. Quality. The quality of work that has been determined by the organization or company

6. Efficiency. Good input and output

\section{Relationship among Variables and Hypothesis Development}

a) The Effect of Job Stress on Employee Productivity

According to [11], where if there is a lack of work space availability, access to office locations from the residence, availability of work equipment, the ability to complete one's own tasks on time, implementing procedures in work, willingness to cooperate with enthusiasm to 
carry out new tasks, hospitality and personal integration. Then the impact of work stress will be high and will certainly affect the ongoing work productivity of employees.

Result Research from [12], Lucia, [13] shows that job stress has a significant effect on employee work productivity.

From the opinion of experts and previous studies, it can be concluded that there is a close relationship and influence between job stress factors and employee work productivity factors.

\section{H1: Job stress has a positive effect on Employee Productivity.}

\section{b) The Effect of Work Environment on Employee Productivity}

To increase productivity, the work environment greatly affects the work productivity of employees, because a good work environment will create ease in carrying out tasks. The work environment itself consists of physical and non-physical work environments that are inherent to employees so that it cannot be separated from efforts to develop employee work productivity. According to [14], he states that "with conductive work environment, employees will feel comfortable and excited and can stimulate motivation so that employee work productivity will increase".

The results of research from [15] show that the work environment has a significant effect on employee work productivity, besides that there are research results.

From the opinion of experts and previous studies, it can be concluded that there is a close relationship and influence between work environment factors and employee work productivity factors.

H2: Work Environment has a positive effect on Employee Productivity.

c) The Effect of Occupational Health and Safety (K3) on Employee Work Productivity

Occupational health and Safety (K3) greatly affects the work productivity of employees, if employees have an accident or illness, for the company there is a double loss, on the one hand the workers cannot produce products, but on the other hand the company has to pay medical expenses, of course for the workers it results in losses.

According to [4], occupational safety and health (K3) is a protection effort aimed at making workers and other people at work or always in a safe and healthy condition so that every source of production can be used safely and efficiently.

The results of research from [16] show that work safety and health have a significant effect on employee work productivity.

From the opinion of experts and previous studies, it can be concluded that there is a close relationship and influence between occupational health safety (K3) factors and employee work productivity factors.

H3: Occupational Health and Safety (K3) has a positive effect on Employee Work Productivity.

\section{Thought Framework}

The thought framework in this study aims to clarify the direction of the research which shows that there is a relationship between work stress, work environment, and occupational health and safety (K3) which affects employee work productivity, so the conceptual framework can be taken with the line of thought depicted in a structure diagram as shown in the picture below. 


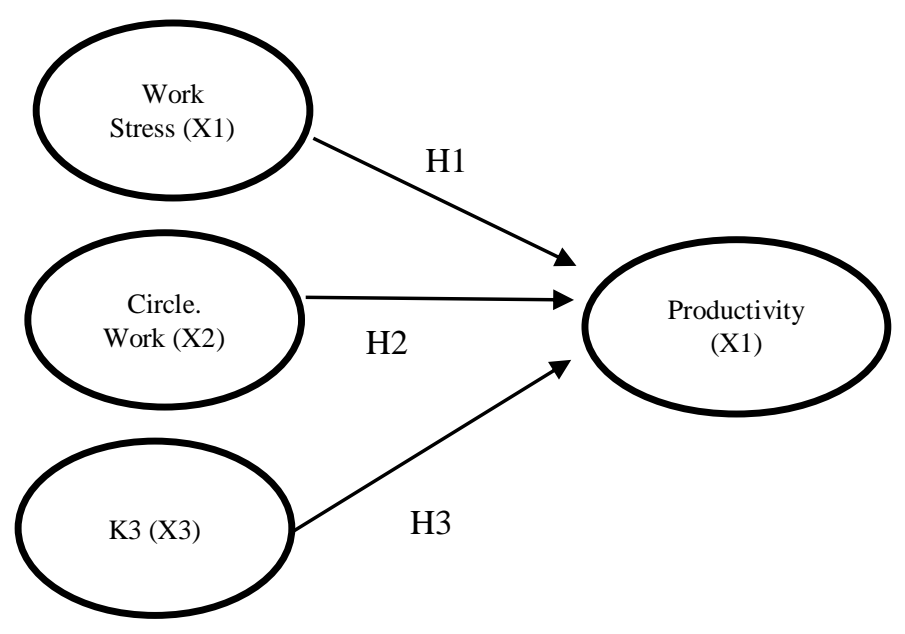

Figure 2.1 Framework

\section{Methods}

This research process begins with the activity of identifying problems where this research was started since November 2019. The author chooses the object of research at PT. Indomika Utama, which is located atJl. Hasyim Ashari No. 45, Gg Jambu, Cipondoh, Tangerang City, Banten 15118.

Design The research used by the author is a causal research method. According to [17], causal research is research that aims to find out about causal relationships in the presence of independent variables (free variables) and dependent variables (dependent variables). This study is intended to determine the effect of work stress, work environment, and occupational health safety (K3) on employee work productivity.

\subsection{Population and Sample Research}

The population used as the object in the study were employees of PT. Indomika Utama, totaling 62 employees. The researcher used saturated sampling as a sampling technique. Saturated sampling is a sampling technique in which all members of the population are sampled. [17], this is often done when the population is relatively small, at least less than 100 people, or research that wants to make generalizations with very small errors. Saturated samples are also often interpreted as being the maximum sample, plus no amount will change the representativeness. With the limited number of population, namely 62, all populations are the samples.

\subsection{Data Collection Techniques and Analysis Methods}

Data collection techniques in this study by conducting surveys, interviews, and distributing questionnaires directly to the research object, namely the employees of PT. Main Indomika.

In the analysis method, there is a concept for measuring data quality, namely reliability and validity. Descriptive statistics are used to provide an overview of the sample data profile. This study uses descriptive statistics consisting of minimum, maximum, mean and standard deviation. 
Descriptive statistics were calculated using Microsoft Excel to facilitate calculations. In addition, in this study, researchers will use the Partial Least Square (PLS) method. PLS is a method of solving structural equation modeling (SEM) which in this case (according to research objectives) is more precise than other SEM technique. Data processing was performed using Microsoft Excel 2010 and PLS 3.0 software.

\section{Results and Discussion}

This hypothesis testing stage is carried out after the structural model evaluation stage is carried out. This stage is carried out to determine whether the research hypothesis proposed in the research model is accepted or rejected. To test the proposed hypothesis, it can be seen from the original sample and the T-Statistic value through the bootsrapping procedure.

According to Helm et al. in Hair et al. [19], the path coefficient values are in the range of values of -1 to +1 , where the path coefficient values that are close to +1 represent a strong positive relationship and the path coefficient values which are -1 indicate a strong negative relationship. Meanwhile, the limit of the t-statistic value for rejecting and accepting the proposed hypothesis is \pm 1.96 , which is if the t-statistic value is in the range of -1.96 and 1.96 then the hypothesis will be rejected or in other words accept the null hypothesis (H0).

Table 1. Hypothesis Testing Results

\begin{tabular}{llllll}
\hline & $\begin{array}{l}\text { Original } \\
\text { Sample (O) }\end{array}$ & $\begin{array}{l}\text { Sample } \\
\text { Mean (M) }\end{array}$ & $\begin{array}{l}\text { Standard } \\
\text { Deviation } \\
(\text { STDEV) }\end{array}$ & $\begin{array}{l}\text { T Statistics }(\mid \mathrm{O} / \\
\text { STDEV } \mid)\end{array}$ & P-Values \\
\hline $\begin{array}{l}\text { X1 (Job Stress) -> Y } \\
\text { (Work Productivity) }\end{array}$ & 0.265 & 0.312 & 0.124 & 2,138 & 0.033 \\
$\begin{array}{l}\text { X2 (Work } \\
\begin{array}{l}\text { Environment) -> Y } \\
\text { (Work Productivity) }\end{array}\end{array}$ & 0.073 & 0.078 & 0.139 & 0.524 & 0.601 \\
$\begin{array}{l}\text { X3 (Work Safety) -> } \\
\text { Y (Work } \\
\text { Productivity) }\end{array}$ & 0.501 & 0.480 & 0.124 & 4,054 & 0.000 \\
\hline
\end{tabular}

Source: Smart PLS Output (2020)

Based on Table 5.20, it can be seen that X1 has a positive and significant effect on Y.This is shown by the test results between the two variables which indicate the original sample value of 0.265 which is close to the value of +1 and has a T-Statistic value of 2.138 (> 1.96).

Based on Table 5.20, it can be seen that X2 has a positive but insignificant effect on Y.This is shown by the test results between the two variables which indicate that the original sample value is 0.073 which is close to the +1 value and has a T-Statistic value. $0.524(<1.96)$.

Based on Table 5.20, it can be seen that X3 has a positive and significant effect on Y.This is shown by the test results between the two variables which indicate the original sample value of 0.501 which is close to the +1 value and has a T-Statistic value. 4,054 (> 1.96).

Discussion This study aims to determine the influence of work stress, work environment, and work safety on work productivity at PT. Indomika Utama Production section. The exogenous variables assessed in this research model are work stress, work environment, and work safety. While the endogenous variable assessed in this research model is work productivity. 
Based on the results of data analysis that have been done above, obtained the calculation value of the R-Square (R2) which shows how good the proposed research model is. From the results of the calculation $(\mathrm{R} 2)$, it can be seen that the endogenous variable work productivity (Y) can be explained by exogenous variables, namely work stress (X1), work environment (X2), and work safety (X3) by $45 \%(0.453)$ while the rest as much as $55 \%$ explained by other exogenous variables.

In addition, the research model was found to have a relevant predictive value with the QSquare (Q2) value of 0.216. Meanwhile, from these resultscould It is known that the model in this study has a good fit because it has a normal fit index (NFI) value which indicates that the model in this study is $47 \%(0.472)$ better than the null model.

Data analysis has been carried out from the conceptualization stage of the model to testing the research hypothesis. The results of the analysis can show whether exogenous variables can influence endogenous variables of work productivity at PT. Indomika Utama Production section. The results of hypothesis testing indicate that of the total three hypotheses tested, two hypotheses are accepted and one hypothesis is rejected.

1. Work stress has a positive and significant effect on work productivity

Based on the test results, the effect of work stress on work productivity has The original sample value is 0.265 which is close to the +1 value and has a T-Statistic value of 2.138 (> 1.96). So it can be concluded that the first hypothesis (H1) is accepted and job stress has a positive and significant effect on work productivity.

The result of this study is supported by previous research conducted by [12] , Lucia, [13] which proves that work stress has a positive and significant effect on work productivity.

2. Work environment has a positive but not significant effect on work productivity

Based on the test results, the effect of the work environment on work productivity has an original sample value of 0.073 which is close to the +1 value and has a T-Statistic value 0.524 $(<1.96)$ so it can be concluded that the second hypothesis (H2) is rejected and the work environment has a positive but insignificant effect on work productivity.

The result of this study is supported by previous research conducted by [15] which proves that the work environment has a positive but insignificant effect on work productivity.

3. Work safety has a positive and significant effect on work productivity

Based on the test results, the effect of work safety on work productivity has an original sample value of 0.501 which is close to the +1 value and has a T-Statistic value 4,054 (> 1.96) so it can be concluded that the third hypothesis (H3) is accepted and work safety has a positive and significant effect on work productivity.

The result of this study is supported by previous research conducted by [16] that work safety has a positive and significant effect on work productivity.

\section{Conclusion}

Work stress has a positive and significant effect on Employee Productivity at PT. Main Indomika. This happens because work stress greatly affects the productivity of employees of PT. Indomika Utama the cause of Work Stress in PT. Indomika Utama is like a demanding job.

Work environment does not have a positive and significant effect on Employee Productivity. This happens because the work environment such as air circulation in the heat operational division makes employees uncomfortable so that it affects the productivity of employees of PT. Main Indomika. 
Work safety has a positive and significant effect on Employee Productivity of PT. Main Indomika. The company has provided safe equipment to employees and good safety and health will show an influence on the work productivity of PT. Main Indomika.

\section{Suggestion}

1. Suggestions for management improvement is to pay more attention to every employee in operational division and ensure that no employee is stressed because of irregular break times, optimizing the available time so that employees are able to complete their work without overtime.

2. The company should provide voting and questionnaires to all employees in the operational division to measure the suitability of the layout of the work equipment to get a layout that is appropriate and according to the wishes of employees, because employees are people who work in that department every day and those who understand better about the layout of the equipment which makes them comfortable while working.

3. Company so that pay more attention to the welfare of its employees by providing insurance to employees, especially in the production department, because work safety in the production section of a company is very important to pay attention to, if there is no insurance, the safety guarantee for employees is not there.

4. Company provide stimulation through incentives and bonuses to employees in order to increase productivity because employees feel excited about the incentives and bonuses given.

\section{References}

[1] D. (1) Sunyoto, Teori, Kuesioner, dan Analisis Data Sumber Daya Manusia. Yogyakarta: CAPS (Center for Academic Publishing Service)., 2012.

[2] M. A. [2] Bandar A, "The Effect Of Human Resource Management Practices On Job Involvement In Selected Private Companies In Jordan,” Can. Soc. Sci., vol. 8, no. 2, pp. 50-57, 2012.

[3] J. L. [3] Gibson, Organisasi Perilaku Struktur Proses., 1st ed. Jakarta: Binapura Aksara., 2011.

[4] M. W. [4] Ardana, K.I., Mujiati N., Utama, Manajemen Sumber Daya Manusia, Pertama. Yogyakarta: PT. Graha Ilmu., 2012.

[5] [5] Wirawan, Menghadapi Stres dan Depresi Seni Menikmati Hidup Agar Selalu Bahagia. Platinum. 2012.

[6] E. J. [6] Rivai, V., \& Sagala, Manajemen sumber Daya Manusia untuk Perusahaan. Penerbit: Rajawali Pers, Jakarta, 2009.

[7] D. [7] Suwatno., \& Juni Priansa, Manajemen Sumber Daya Manusia. Bandung: Alfabeta., 2011.

[8] [8] Yani, H.M., Manajemen Sumber Daya Manusia. Jakarta: Mitra Wacana Media., 2012.

[9] E. [10] Sutrisno, Manajemen Sumber Daya Manusia, Edisi Pert. Jakarta: Penerbit Kencana., 2009.

[10] [11] Moekijat., Manajemen Sumber Daya Manusia. Bandung: Mandar Maju., 2010.

[11] B. [12] Miranda, "Pengaruh Kecerdasan Emosional, Stres Kerja Dan Kompensasi Finansial Terhadap Kinerja Pegawai (Studi Kasus Di PT. Permata Bank, Tbk. Area Banten," vol. 1, 2014.

[12] [13] Cherny and Kartikasari., "Pengaruh Stres dan Motivasi Terhadap Produktivitas Kerja 
Karyawan Pada PT Epsom Batam,” J. Akuntansi, Ekon. dan Manaj. Bisnis, vol. 5, no. 1, 2017.

[13] K. and T. [14] Lucia, "Pengaruh Konflik dan Stres Kerja Terhadap Produktivitas Kerja di mediasi oleh Kepuasan Kerja Karyawan,” Jurnam EMBA, vol. 3, no. 3, 2015.

[14] [15] Sedarmayanti., Tata Kerjadan Produktivitas Kerja. Bandung: CV Mandar Maju., 2011.

[15] S. [16] Sinaga, "Pengaruh Lingkungan Kerja Terhadap Produktivitas Kerja Karyawan," JOM FISIP, vol. 3, no. 2, 2016.

[16] [17] Kaligis dan Langitan, "Pengaruh Implementasi Program Keselamatan dan Kesehatan Kerja Terhadap Produktivitas Kerja,” J. Sipil Statik, vol. 1, no. 3, 2013.

[17] Sugiyono, Metode Penelitian Bisnis. Alfabetha, Bandung, 2013. 